\title{
KARAKTERISTIK TABLET EFFERVESCENT LABU SIAM (Sechium edule Sw.) DAN EKSTRAK SECANG (Caesalpinia sappan L.) DENGAN FILLER LAKTOSA- MANITOL
}

\author{
CHARACTERISTIC OF CHAYOTE (Sechium edule Sw.) AND SECANG (Caesalpinia sappan \\ L.) EFFERVESCENT WITH LACTOSE-MANNITOL FILLER
}

Natalia Datik Sulistiani, Choirul Anam, Bara Yudhistira

Program Studi Ilmu dan Teknologi Pangan, Fakultas Pertanian, Universitas Sebelas Maret, Surakarta Email: nataliadatik@gmail.com

Diserahkan [7 Juni 2018]; Diterima [14 Agustus 2018]; Dipublikasi [31 Agustus 2018]

\begin{abstract}
Effervescent products are preferred by consumers because they have the advantage of being practical, easily reconstituted and have a refreshing sensation when taken. In its manufacture, the filler also determines the characteristics of the resulting tablet. The main ingredients that can be used in making effervescent are chayote and secang. Chayote and secang have antioxidant compounds. The purpose of this research is to know the influence of filler material ie lactose-mannitol to chemical, physical granule, physical tablet and effervescent senservousent of squash and secang extract. This study used Completely Randomized Design (CRD) with one factor, which was the variation of proportion lactose and mannitol (100: 0\%, 80: 20\%; 50: 50\%; 20: 80\% and 0: 100\%). The data obtained were analyzed statistically with One Way Analysis of Variance (ANOVA) method. If it shows significant results, then continued testing using Duncan's Multiple Range Test (DMRT) at significance level $\alpha=0.05$. The results showed that the use of lactose-mannitol as a filler effect on porosity, compressibility, flow rate, granular diameter, hardness, brittleness, soluble time of tablet, color and appearance of tablets and effervescent effervescence and effluent but not significantly influence water content, $\mathrm{pH}$, antioxidant activity, appearance and smell of effervescent beverages. Selected formulations based on weighted test were effervescent chayote and secang extract with lactose 20\%: mannitol 80\% filler which had antioxidant activity 3,385\% and tablet solubility time 1,779 minute.
\end{abstract}

Keyword: chayote, secang, mannitol, lactose, effervescent, antioxidant

\section{ABSTRAK}

Produk effervescent disukai konsumen karena memiliki keuntungan yaitu praktis, mudah dilarutkan dan mempunyai sensasi menyegarkan ketika diminum. Dalam pembuatannya, bahan pengisi juga menentukan karakteristik tablet yang dihasilkan. Bahan utama yang bisa digunakan dalam pembuatan effervescent yaitu labu siam dan ekstrak secang. Labu siam maupun secang mempunyai senyawa antioksidan. Penelitian ini bertujuan untuk mengetahui pengaruh bahan pengisi yaitu laktosamanitol terhadap sifat kimia, fisik granul, fisik tablet serta sensoris effervescent labu siam dan ekstrak secang. Penelitian ini menggunakan Rancangan Acak Lengkap (RAL) dengan satu faktor yaitu penggunaan laktosa-manitol sebagai bahan pengisi dengan variasi konsentrasi laktosa-manitol sebesar 100:0\%, 80:20\%; 50:50\%; 20:80\% dan 0:100\%. Data yang diperoleh dianalisis statistik dengan metode One Way Analysis of Varians (ANOVA). Apabila menunjukkan hasil yang siginifikan, maka dilakukan pengujian lanjutnya dengan menggunakan analisis Duncan's Multiple Range Test (DMRT) pada taraf signifikansi $\alpha=0,05$. Hasil menunjukan penggunaan laktosa-manitol sebagai bahan pengisi berpengaruh terhadap porositas, kompresibilitas, kecepatan alir, sudut diam granul, kekerasan, kerapuhan, waktu larut tablet, warna dan kenampakan tablet serta rasa dan overall minuman effervescent, namun tidak berpengaruh secara signifikan terhadap kadar air, $\mathrm{pH}$, aktivitas antioksidan, kenampakan dan aroma minuman effervescent. Formulasi terpilih berdasarkan uji pembobotan yaitu effervescent labu siam dan ekstrak secang dengan pengisi laktosa 20\% : manitol $80 \%$ dimana memiliki aktivitas antioksidan sebesar 3,385\% dan waktu larut tablet 1,779 menit.

Kata kunci: labu siam, secang, manitol, laktosa, effervescent, antioksidan 


\section{PENDAHULUAN}

Semakin majunya teknologi dibidang industri pangan membuat semakin banyak inovasi produk pangan yang mengunggulkan berbagai manfaat produk tersebut. Salah satu produk minuman yang saat ini disukai masyarakat adalah effervescent. Effervescent merupakan granul atau tablet yang mengandung asam dan basa atau bahanbahan lain yang mampu melepaskan gas ketika bercampur dengan air (Ansar dkk., 2006).

Produk effervescent digemari oleh konsumen karena proses penyajiannya lebih mudah dan praktis. Keunggulan lain dari tablet effervescent yaitu mudah larut. Sebagai minuman penyegar, penyajian effervescent hanya perlu dilarutkan ke dalam air mineral. Dan dalam waktu yang singkat tablet tersebut sudah siap untuk dinikmati (Allen et al., 2009). Selain praktis, effervescent disukai karena dapat membentuk larutan yang memberikan efek sparkle seperti pada rasa minuman bersoda (BPOM, 2014).

Langkah awal dalam pembuatan tablet effervescent adalah menentukan formulasi agar bisa didapatkan tablet yang memenuhi kriteria. Masalah yang sering terjadi yaitu tablet yang dihasilkan bersifat rapuh sehingga mudah hancur, ataupun terlalu mampat sehingga sukar larut (Ansar dkk, 2009). Hal tersebut yang membuat penentuan formulasi bahan utama maupun bahan tambahan harus diperhatikan salah satunya bahan pengisi.

Bahan pengisi merupakan salah satu bahan yang mempengaruhi karakteristik tablet effervescent. Bahan yang bisa digunakan sebagai pengisi dalam pembuatan effervescent yaitu laktosa dan manitol. Baik laktosa maupun manitol masing-masing memiliki keunggulan. Bahan pengisi ditambahkan ke dalam formulasi untuk memudahkan proses pemadatan/ pengempaan. Manitol merupakan pengisi yang relatif mahal. Sedangkan laktosa atau gula susu merupakan salah satu bahan yang paling umum digunakan sebagai pengisi dalam pembuatan tablet. Daya larut dan kemanisannya lebih sedikit dibandingkan dengan gula yang lain (Kailaku, 2012).
Manitol memiliki sifat non higroskopis sehingga bisa digunakan untuk bahan yang sensitif terhadap kelembaban. Granulasi yang menggunakan manitol juga mempunyai keuntungan yaitu mudah dikeringkan (Lumay et al., 2012).

Dalam pembuatan effervescent, bahan yang digunakan bisa berasal dari produk holtikultura, diantaranya yaitu secang dan labu siam. Kayu secang mengandung brazilin. Brazilin yang merupakan komponen terbesar dari kayu secang merupakan senyawa antioksidatif yang memiliki gugus catechol pada struktur kimianya. Berdasarkan sifat antioksidannya, brazilin merupakan pelindung terhadap bahaya radikal bebas pada sel (Juliyanto, 2010). Adanya kandungan flavonoid dan senyawa fenolat lainnya pada kayu secang, mengindikasi secang berpotensi sebagai antioksidan (Koswara, 2009).

Labu siam (Sechium edule $S w$ ) merupakan salah satu jenis tanaman yang biasanya dimanfaatkan sebagai sayuran. Labu siam mudah didapatkan di pasar-pasar dan harganya terjangkau. Produksi labu siam di Indonesia dari tahun 2009 sampai 2012 mengalami kenaikan. Dari data tersebut produksi labu siam terbesar berasal dari daerah Jawa dengan rata-rata hasil produksi sebesar 78,45 Ton/Ha (Bhise et al., 2014).

Labu siam memiliki beberapa manfaat dan kegunaan terhadap kesehatan. Salah satu khasiat dari labu siam adalah mampu menurunkan tekanan darah tinggi (Hartono dan Punwidya, 2008). Labu siam juga memiliki senyawa antioksidan yaitu senyawa polifenol, flavonoid, proantosianidin, vitamin A, dan vitamin C (Rowe et al., 2006).

Berdasarkan penjelasan tersebut maka penelitian ini bertujuan untuk mengetahui penggunaan bahan pengisi yaitu laktosamanitol terhadap karakteristik tablet effervescent labu siam (Sechium edule $S w$ ) dengan penambahan ekstrak secang (Caesalpinia sappan L.).

\section{METODE PENELITIAN}

Alat

Alat-alat yang digunakan dalam proses pembuatan effervescent yaitu baskom, pisau, telenan, saringan, juicer, timbangan, gelas 
ukur, erlenmeyer, gelas beker, magnetic stirer, spray dryer, neraca analitik, loyang, shaker, sendok, oven, mortar, ayakan 80 mesh, pencetak tablet single punch, neraca analitik. Alat-alat yang digunakan untuk analisis diantaranya $\mathrm{pH}$ meter, gelas beker, oven, desikator, botol timbang, penjepit, neraca analitik, spektofotometer, kuvet, tabung reaksi, alumunium foil, vortex, pipet volume, propipet, gelas ukur, piknometer, corong, stopwatch, statif, jangka sorong, penggaris, Hardness tester, Friability tester, gelas, cawan dan sendok.

\section{Bahan}

Bahan yang digunakan untuk pembuatan effervescent labu siam dan ekstrak secang yaitu labu siam yang diperoleh dari Tawangmangu, Karanganyar, ekstrak secang, maltodekstrin, asam sitrat, natrium bikarbonat, aspartam, polivinilpirolidin (PVP), manitol, dan laktosa. Bahan yang digunakan untuk analisis yaitu metanol, DPPH, parafin, aquades, dan air mineral.

\section{Tahapan Penelitian}

\section{Pembuatan Sari Labu Siam}

Labu siam yang sehat, tidak cacat dan berwarna hijau dipotong menjadi dua dan digosok-gosok sampai keluar getahnya. Setelah itu dikupas, dicuci dan direndam dalam air selama 10 menit dan dikeringanginkan (Pribadi dkk., 2014). Kemudian labu siam dipotong-potong dan dihancurkan dengan menggunakan juicer untuk mendapatkan sarinya. Sari yang sudah didapatkan kemudian disaring lalu ditimbang.

\section{Pembuatan Serbuk Labu Siam}

Langkah pembuatan serbuk labu siam ini dilakukan dengan cara menambahkan maltodekstrin sebanyak $8 \%$ ke dalam sari labu siam. Kemudian dilakukan pengeringan menggunakan spray dryer dengan suhu inlet $120^{\circ} \mathrm{C}$ dan outlet $80-90^{\circ} \mathrm{C}$. Selama proses pembuatan serbuk, sari labu siam terus diaduk dengan menggunakan magnetik stirer.

\section{Pembuatan Granul Effervescent}

Pembuatan effervescent dilakukan dengan cara dibuat 2 campuran terpisah. Campuran pertama terdiri dari ekstrak secang, aspartam, manitol, dan laktosa sedangkan campuran kedua yaitu natrium bikarbonat, pvp dan serbuk labu siam. Pemisahan dilakukan agar tidak terjadi reaksi dini antara asam dengan basa (Setiawan, 2012). Setelah dicampur, bahan-bahan tersebut diayak. Selanjutnya dilakukan pengeringan bahan-bahan tersebut menggunakan oven dengan suhu $40^{\circ} \mathrm{C}$ selama 15 menit. Setelah itu granul yang terbentuk dihaluskan dengan mortar kemudian diayak. Kemudian di oven kembali dengan suhu $70^{\circ} \mathrm{C}$ selama 15 menit. Bahan pengisi yang digunakan dengan variasi konsentrasi laktosa-manitol sebesar 100:0\%, $80: 20 \% ; 50: 50 \% ; 20: 80 \%$ dan 0:100\%.

\section{Pembuatan Tablet Effervescent}

Granul yang telah jadi kemudian ditimbang sebanyak 500 mg. Kemudian dimasukkan ke dalam pencetak tablet single punch yang berbentuk bulat. Cara kerja dari pencetak tablet ini yaitu pengempaan granul ketika terjadi gerakan punch atas dan punch bawah (Ansel, 1989). Ketika akan dicetak, alat pencetak diolesi magnesium stearat terlebih dahulu yang berfungsi sebagai pelincir/lubrikan agar granul tidak menempel pada alat.

\section{Analisis Kimia, Fisik, dan Sensoris}

Analisis kimia yang dilakukan antara lain uji kadar air menggunakan metode thermogravimetri (AOAC, 1999), $\mathrm{pH}$ atau uji derajat keasaman (Wijaya dkk., 2014), uji aktivitas antioksidan dengan metode DPPH (Setiawan, 2012). Analisis fisik granul meliputi porositas dengan alat piknometer, kompresibilitas atau uji pengetapan, kecepatan alir dan sudut diam dengan alat corong (Lachman dkk., 1989). Analisis fisik tablet meliputi kekerasan dengan alat Hardness tester dan kerapuhan dengan alat Friability Tester (Allen et al., 2009), waktu larut (Kholidah dkk, 2014), keseragaman bobot (BPOM, 2014), dan keseragaman ukuran (diameter dan ketebalan) dengan alat jangka sorong (Tomar et al., 2012). Analisis sensoris dengan metode hedonik (Pribadi dkk, 2014). Uji pembobotan atau penentuan formulasi terbaik dengan metode Compensatory (Sullivan et al., 2015). 


\section{Analisis Data}

Data analisis kimia, fisik, dan sensoris, yang diperoleh dianalisis secara statistik dengan metode one way ANOVA. Jika menunjukkan hasil yang signifikan maka dilanjutkan dengan uji beda nyata menggunakan Duncan's Multiple Range Test (DMRT) pada taraf signifikansi $\alpha=0,05$.

\section{HASIL DAN PEMBAHASAN}

\section{Evaluasi Sifat Kimia Granul \& Tablet Effervescent}

Tabel 1 Hasil Analisis Sifat Kimia Granul \& Tablet Effervescent

\begin{tabular}{cccc}
\hline Formulasi & $\begin{array}{c}\text { Kadar } \\
\text { air }(\%)\end{array}$ & pH & $\begin{array}{c}\text { Aktivitas } \\
\text { antioksidan } \\
\%\end{array}$ \\
\hline F1 & $3,781^{\mathrm{a}} \pm$ & $6,483^{\mathrm{a}} \pm$ & $3,342^{\mathrm{a}} \pm$ \\
& 0,274 & 0109 & 0,218 \\
F2 & $3,765^{\mathrm{a}} \pm$ & $6,488^{\mathrm{a}} \pm$ & $3,212^{\mathrm{a}} \pm$ \\
& 0,786 & 0,070 & 0,224 \\
F3 & $3,593^{\mathrm{a}} \pm$ & $6,359^{\mathrm{a}} \pm$ & $3,385^{\mathrm{a}} \pm$ \\
& 0,778 & 0,055 & 0,224 \\
F4 & $3,340^{\mathrm{a}} \pm$ & $6,435^{\mathrm{a}} \pm$ & $3,385^{\mathrm{a}} \pm$ \\
& 0,307 & 0,046 & 0,100 \\
F5 & $3,225^{\mathrm{a}} \pm$ & $6,420^{\mathrm{a}} \pm$ & $3,429^{\mathrm{a}} \pm$ \\
& 0,256 & 0,011 & 0,218 \\
\hline
\end{tabular}

*notasi huruf yang berbeda menunjukkan beda nyata antar baris pada taraf signifikasi $(\alpha) 5 \%$. Keterangan : F1 : Laktosa $100 \%$, F2 : Laktosa $80 \%$ : Manitol 20\%, F3 : Laktosa 50\% : Manitol 50\%, F4 : Laktosa 20\% : Manitol 80\%, F5 : Manitol 100\%

\section{Kadar Air}

Berdasarkan Tabel 1 granul yang menggunakan pengisi manitol mempunyai kadar air yang lebih rendah dari granul yang menggunakan pengisi laktosa. Kadar air yang dihasilkan berkisar antara 3,225-3,781. Manitol bersifat non higroskopis. Formulasi yang menggunakan manitol dapat dikeringkan dengan mudah (Rowe et al., 2006). Hal ini yang menyebabkan formulasi yang menggunakan manitol memiliki kadar air yang lebih rendah. Namun secara keseluruhan, hasil tidak berbeda nyata.

\section{pH}

$\mathrm{pH}$ larutan effervesent dikatakan baik jika $\mathrm{pH}$ mendekati netral yakni pH 6-7 (Kailaku, 2012). Dari Tabel 1 dapat diketahui bahwa hasil uji tidak berbeda nyata, yang berarti penggunaan pengisi laktosa, manitol dan kombinasinya tidak mempengaruhi nilai $\mathrm{pH}$ secara signifikan. Tablet effervescent berada pada pH kisaran 6,359-6,488. Tablet effervescent bersifat asam, karena komposisi paling banyak dalam pembuatan effervescent yaitu asam sitrat. Penurunan nilai $\mathrm{pH}$ disebabkan dengan meningkatnya jumlah ion $\mathrm{H}+$ dari asam (Violalita dan Rini, 2015).

\section{Aktivitas antioksidan \\ Antioksidan adalah semua senyawa yang dapat meredam dan atau menonaktifkan serangan radikal bebas (Rusli dkk., 2005). Penentuan nilai aktivitas antioksidan ini dengan menggunakan metode DPPH. Berdasarkan Tabel 1 didapatkan hasil uji aktivitas antioksidan tidak berbeda nyata. Nilai aktivitas antioksidan yang didapat berkisar antara 3,21-3,42\%. Penurunan aktivitas antioksidan dipengaruhi ketika nilai $\mathrm{pH}$ dalam keadaan semakin basa atau netral (Ismaeil et al., 2016).}

\section{Evaluasi Sifat Fisik Granul Effervescent}

Tabel 2 Hasil Analisis Sifat Fisik Granul Effervescent

\begin{tabular}{ccccc}
\hline Formulasi & Porositas (\%) & $\begin{array}{c}\text { Kompresibilitas } \\
(\%)\end{array}$ & $\begin{array}{c}\text { Kecepatan Alir } \\
(\mathrm{g} / \mathrm{s})\end{array}$ & Sudut Diam $\left(^{\circ}\right)$ \\
\hline F1 & $63,842^{\mathrm{b}} \pm 1,653$ & $15,848^{\mathrm{b}} \pm 0,354$ & $5,823^{\mathrm{c}} \pm 0,479$ & $30,050^{\mathrm{c}} \pm 0,395$ \\
F2 & $61,970^{\mathrm{ab}} \pm 2,217$ & $15,455^{\mathrm{ab}} \pm 1,159$ & $6,056^{\mathrm{c}} \pm 0,320$ & $29,743^{\mathrm{bc}} \pm 0,165$ \\
F3 & $61,235^{\mathrm{ab}} \pm 2,599$ & $14,242^{\mathrm{ab}} \pm 0,759$ & $5,024^{\mathrm{b}} \pm 0,207$ & $29,270^{\mathrm{b}} \pm 0,519$ \\
F4 & $61,128^{\mathrm{ab}} \pm 0,365$ & $14,143^{\mathrm{ab}} \pm 2,106$ & $4,614^{\mathrm{ab}} \pm 0,415$ & $27,939^{\mathrm{a}} \pm 0,390$ \\
F5 & $60,519^{\mathrm{a}} \pm 1,641$ & $13,597^{\mathrm{a}} \pm 0,850$ & $4,278^{\mathrm{a}} \pm 0,550$ & $27,393^{\mathrm{a}} \pm 0,561$ \\
\hline
\end{tabular}

*notasi huruf yang berbeda menunjukkan beda nyata antar baris pada taraf signifikasi $(\alpha) 5 \%$.

Keterangan : F1 : Laktosa 100\%, F2 : Laktosa 80\% : Manitol 20\%, F3 : Laktosa 50\% : Manitol $50 \%$, F4 : Laktosa 20\% : Manitol 80\%, F5 : Manitol 100\% 


\section{Porositas}

Porositas merupakan ruang kosong antar partikel pada granul (Faradiba dkk., 2013). Berdasarkan Tabel 2, diperoleh porositas semakin menurun. Porositas tertinggi didapatkan pada effervescent labu siam dan ekstrak secang dengan pengisi laktosa $100 \%$ dan yang terendah pada manitol $100 \%$. Adanya beda nyata antara F1 (pengisi laktosa 100\%) dengan F5 (manitol 100\%) disebabkan karena F1 memliki kadar air lebih tinggi dibandingkan F5. Dengan meningkatnya kadar air, volume partikel akan meningkat lebih signifikan dibandingkan masanya. Volume partikel meningkat karena ukuran partikel menjadi lebih besar dan menyebabkan rongga antar partikel lebih besar pula (Bhise et al., 2014).

\section{Kompresibilitas}

Porositas dan kompresibilitas suatu bahan tergantung pada ukuran partikel dan bentuk. Bila partikel bahan lebih berongga dan ketahanan terhadap pemampatan rendah, maka serbuk lebih kompresibel (mudah dimampatkan). Sifat aliran granul berdasarkan kompresibilitas granul dapat dilihat dari nilai indeks Carr's. Granul mempunyai sifat aliran yang baik jika mempunyai nilai indeks Car's $11-15 \%$, jika lebih besar maka sifat alirannya semakin buruk (Saifullah dkk., 2016). Berdasarkan Tabel 2 diperoleh nilai kompresibilitas semakin menurun. Nilai kompresibilitas tertinggi didapatkan pada effervescent labu siam dan ekstrak secang dengan pengisi laktosa $100 \%$ dan yang terendah pada manitol 100\%. Sama halnya dengan porositas, adanya beda nyata antara F1 (pengisi laktosa 100\%) dengan F5 (manitol $100 \%$ ) diduga disebabkan karena granul dengan pengisi laktosa memiliki kadar air lebih tinggi dibandingkan granul dengan pengisi manitol. Kadar air yang meningkat, ukuran partikel menjadi lebih besar dan lebih berongga. Partikel yang lebih berongga dan ketahanannya terhadap pemampatan lebih rendah, maka partikel lebih kompresibel (mudah dimampatkan) (Saifullah dkk., 2016).

\section{Kecepatan Alir}

Uji aliran granul/kecepatan alir granul dilakukan untuk mengetahui homogenitas granul dan keseragaman pengisian granul (Kailaku, 2012). Granul dengan sifat aliran yang baik yaitu granul yang memiliki kecepatan alir 4-10 g/s [35]. Berdasarkan Tabel 2, didapatkan kecepatan alir tertinggi yang menggunakan pengisi laktosa $80 \%$ : manitol 20\%. Laktosa mempunyai densitas $1,545 \mathrm{~g} / \mathrm{cm}^{3}$ dan bobot molekul 360,31 g/mol lebih besar dari manitol yaitu $1,514 \mathrm{~g} / \mathrm{cm}^{3}$ dan 182,17 g/mol (Rowe et al., 2006). Densitas yang lebih besar akan memiliki berat molekul yang lebih besar sehingga akan semakin mudah mengalir karena gaya gravitasi semakin besar (Anwar, 2010). Semakin tinggi densitas massa granul menyebabkan waktu alirnya semakin cepat (Pratiwi dkk., 2011).

\section{Sudut Diam}

Sudut diam merupakan sudut maksimal yang terjadi antara permukaan suatu tumpukan granul dan bidang horizontal (Faradiba dkk., 2013).. Granul yang memiliki sifat aliran baik adalah granul yang memiliki sudut diam kurang dari $35^{\circ}$ (Lumay et al., 2012). Berdasarkan Tabel 2 didapatkan nilai sudut diam semakin kecil dengan kisaran nilai $27-30^{\circ}$. Nilai sudut diam semakin kecil menunjukkan sifat alir yang semakin baik. Nilai sudut diam granul yang menggunakan pengisi laktosa lebih banyak dari manitol menghasilkan sudut diam yang semakin besar. Hal ini disebabkan oleh granul yang menggunakan laktosa mempunyai kadar air lebih tinggi. Sudut diam semakin besar seiring meningkatnya kadar air yang tinggi (Bhise et al, 2014).. Kadar air yang tinggi cenderung membuat granul mengalir secara tidak merata (menyebar) dan menghasilkan sudut yang besar (Lieberman et al., 1989).

\section{Evaluasi Sifat Fisik Tablet Effervescent}

\section{Kekerasan}

Kekerasan tablet juga merupakan parameter yang menggambarkan ketahanan dalam melawan tekanan mekanik seperti gocangan, kikisan, dan keretakan tablet selama packing dan distribusi (Abdillah, 2012). Dalam bidang industri kekuatan 
tekanan minimum yang sesuai untuk tablet adalah sebesar 4 kgf (Ansel, 1989). Berdasarkan Tabel 3, kekerasan tablet paling tinggi yaitu pada pengisi Laktosa $80 \%$ : manitol 20\% dan terendah pada pengisi manitol $100 \%$. Kekerasan tablet yang tinggi diakibatkan karena kadar air yang cukup tinggi pada granul. Sehingga saat di kompresi/dicetak, granul mudah dipadatkan dan mempunyai daya lekat yang tinggi antar partikel (Eichi dan Kadehinbu, 2009). Laktosa memberikan kompresibilitas yang lebih baik bila dibandingkan dengan manitol sehingga ikatan antar partikel lebih kuat dan tablet yang dihasilkan semakin keras (Pudiastuti dkk., 2009). Kenaikan kadar air membuat tablet menjadi lebih lengket dan tidak dapat hancur secara mudah (Violalita dan Rini, 2015)..

\section{Kerapuhan}

Kerapuhan yang baik memiliki nilai kurang dari 1\%. Berdasarkan Tabel 3 kerapuhan masih masuk dalam standar yaitu kurang dari $1 \%$. Granul yang menggunakan laktosa lebih banyak menyebabkan kerapuhannya lebih kecil dibandingkan dengan pengisi manitol. Kenaikan kadar air membuat tablet menjadi lebih lengket dan tidak dapat hancur secara mudah, sehingga kerapuhannya juga kecil (Violalita dan Rini, 2015)..

\section{Waktu Larut}

Standar waktu larut tablet effervescent yang ditetapkan oleh United States Pharmacopoeia (USP) adalah 2 menit (Ansar dkk, 2010). Syarat waktu hancur effervescent yaitu $\leq 5$ menit. Berdasarkan Tabel 3, waktu larut yang paling lama yaitu dengan pengisi laktosa $80 \%$ : manitol $20 \%$ yaitu 2,117 menit. Hal ini karena tablet tersebut mempunyai kekerasan yang lebih tinggi dibandingkan ke empat formulasi lainnya. Sehingga dapat diketahui bahwa formulasi tablet dengan pengisi laktosa $80 \%$ : manitol $20 \%$ memiliki waktu larut yang melebihi standar persyaratan, yaitu maksimal 2 menit.

\section{Keseragaman Bobot}

Syarat dari Farmakope Indonesia, penyimpangan bobot tablet yang mempunyai berat diatas $300 \mathrm{mg}$ yaitu tidak lebih dari 5\% dan 10\% (Abdillah, 2012). Berdasarkan Tabel 4, bobot tablet yang didapat berkisar 464-472 mg dan tidak berbeda nyata antar formulasi. Dari tabel tersebut juga menunjukkan hasil penyimpangan bobot tablet $(\mathrm{CV})$. Nilai $\mathrm{CV}$ diperoleh dengan membagi standar deviasi dengan bobot ratarata tablet. Berdasarkan hasil analisa didapatkan bahwa semua granul memiliki CV kurang dari 5\% dan tidak berbeda nyata. Sehingga dapat diketahui bahwa semua formulasi memiliki penyimpangan bobot yang masih masuk syarat.

\section{Keseragaman Ukuran (Diameter dan Ketebalan)}

Syarat ukuran tablet (Departemen Kesehatan RI, 1979), diameter tablet tidak lebih dari $3 \mathrm{x}$ dan kurang dari 1 1/3 tebal tablet (Hartono dan Punwidya, 2008). Berdasarkan Tabel 4 penggunaan pengisi laktosa-manitol tidak berpengaruh secara signifikan terhadap diameter dan ketebalan tablet. Selain itu ukuran tablet juga memenuhi standar persyaratan yaitu diameternya tidak lebih dari 3x tebalnya.

Tabel 3 Hasil Analisis Sifat Fisik Tablet Effervescent

\begin{tabular}{cccc}
\hline Formulasi & Kekerasan $(\mathrm{kgF})$ & Kerapuhan $(\%)$ & Waktu larut (menit) \\
\hline F1 & $6,078^{\mathrm{ab}} \pm 0,826$ & $0,505^{\mathrm{ab}} \pm 0,055$ & $1,917^{\mathrm{a}} \pm 0,187$ \\
$\mathrm{~F} 2$ & $6,503^{\mathrm{b}} \pm 0,478$ & $0,480^{\mathrm{a}} \pm 0,047$ & $2,117^{\mathrm{a}} \pm 0,116$ \\
$\mathrm{~F} 3$ & $5,800^{\mathrm{ab}} \pm 0,360$ & $0,514^{\mathrm{ab}} \pm 0,092$ & $1,946^{\mathrm{a}} \pm 0,500$ \\
F4 & $5,588^{\mathrm{a}} \pm 0,479$ & $0,548^{\mathrm{ab}} \pm 0,044$ & $1,779^{\mathrm{a}} \pm 0,311$ \\
F5 & $5,283^{\mathrm{a}} \pm 0,258$ & $0,593^{\mathrm{b}} \pm 0,021$ & $1,668^{\mathrm{a}} \pm 0,186$ \\
\hline *notasi huruf yang berbeda menunjukkan beda nyata antar baris pada taraf signifikasi $(\alpha) 5 \%$. \\
Keterangan : F1 : Laktosa 100\%, F2 : Laktosa 80\% : Manitol 20\%, F3 : Laktosa 50\% : Manitol 50\%, F4 : \\
Laktosa 20\% : Manitol 80\%, F5 : Manitol 100\%
\end{tabular}


Tabel 4 Hasil Analisis Keseragaman Fisik Tablet Effervescent

\begin{tabular}{ccccc}
\hline Formulasi & Keseragaman bobot $(\mathrm{mg})$ & CV $(\%)$ & Ketebalan $(\mathrm{cm})$ & Diameter $(\mathrm{cm})$ \\
\hline F1 & $464,488^{\mathrm{a}} \pm 6,587$ & 1,418 & $0,431^{\mathrm{a}} \pm 0,024$ & $1,281^{\mathrm{a}} \pm 0,239$ \\
F2 & $466,613^{\mathrm{a}} \pm 8,845$ & 1,896 & $0,444^{\mathrm{a}} \pm 0,024$ & $1,306^{\mathrm{a}} \pm 0,052$ \\
F3 & $470,313^{\mathrm{a}} \pm 7,691$ & 1,636 & $0,450^{\mathrm{a}} \pm 0,134$ & $1,338^{\mathrm{a}} \pm 0,060$ \\
F4 & $471,025^{\mathrm{a}} \pm 3,825$ & 0,810 & $0,463^{\mathrm{a}} \pm 0,189$ & $1,369^{\mathrm{a}} \pm 0,085$ \\
F5 & $472,225^{\mathrm{a}} \pm 9,473$ & 2,012 & $0,469^{\mathrm{a}} \pm 0,094$ & $1,356^{\mathrm{a}} \pm 0,052$ \\
\hline
\end{tabular}

*notasi huruf yang berbeda menunjukkan beda nyata antar baris pada taraf signifikasi $(\alpha) 5 \%$.

Keterangan : F1 : Laktosa 100\%, F2 : Laktosa 80\% : Manitol 20\%, F3 : Laktosa 50\% : Manitol $50 \%$, F4 : Laktosa 20\% : Manitol 80\%, F5 : Manitol 100\%

\section{Evaluasi Sensoris Tablet dan Minuman Effervescent}

\section{Warna Tablet}

Dari parameter warna tablet, tablet dengan pengisi laktosa $80 \%$ : manitol 20 berbeda nyata dengan tablet pengisi laktosa laktosa $100 \%$, laktosa $20 \%$ : manitol $80 \%$ dan manitol $100 \%$. Adanya beda nyata antar tablet diduga karena adanya pemanasan/pengeringan dalam pembuatan granul. Proses pemanasan dapat menyebabkan perubahan warna maupun flavor produk (Estiasih dan Ahmadi, 2009). Nilai rata-rata tingkat kesukaan panelis terhadap warna tablet effervescent labu siam dan ekstrak secang berkisar 3,44-4,24 dengan nilai netral sampai suka.

\section{Kenampakan tablet}

Berdasarkan Tabel 5, terdapat beda nyata antara penggunaan pengisi laktosa dengan manitol. Hal ini diduga berhubungan dengan kompresibilitas maupun saat proses pencetakan tablet. Tablet dengan pengisi laktosa memiliki kompresibilitas yang tinggi (mudah dikompresi) sehingga tablet yang terbentuk mempunyai ketebalan yang lebih kecil dibandingkan dengan tablet yang menggunakan pengisi manitol. Nilai rata-rata tingkat kesukaan panelis terhadap kenampakan tablet effervescent labu siam dan ekstrak secang berkisar 3,40-4,20 dengan kisaran nilai netral hingga suka. Dari parameter kenampakan tablet, yang paling disukai yaitu tablet dengan pengisi laktosa $20 \%$ : manitol $80 \%$.

\section{Kenampakan minuman}

Parameter kenampakan minuman effervescent diamati setelah tablet dilarutkan dalam air mineral. Kenampakan yang diamati yaitu warna maupun buih. Berdasarkan Tabel 5 penggunaan pengisi laktosa-manitol tidak berpengaruh secara signifikan terhadap tingkat penerimaan panelis pada kenampakan minuman effervescent. Nilai rata-rata tingkat kesukaan panelis terhadap kenampakan minuman effervescent labu siam dan ekstrak secang berkisar 3,60-3,84 dengan nilai netral. Dari parameter kenampakan minuman, yang paling disukai yaitu tablet dengan pengisi laktosa 20\% : manitol $80 \%$.

Tabel 5 Hasil Uji Sensoris

\begin{tabular}{cllllll}
\hline Formulasi & $\begin{array}{l}\text { Warna } \\
\text { Tablet }\end{array}$ & $\begin{array}{l}\text { Kenampakan } \\
\text { Tablet }\end{array}$ & $\begin{array}{l}\text { Kenampakan } \\
\text { Minuman }\end{array}$ & $\begin{array}{l}\text { Aroma } \\
\text { Minuman }\end{array}$ & $\begin{array}{l}\text { Rasa } \\
\text { Minuman }\end{array}$ & Overall \\
\hline F1 & $4,00^{\mathrm{b}}$ & $3,40^{\mathrm{a}}$ & $3,72^{\mathrm{a}}$ & $3,20^{\mathrm{a}}$ & $3,92^{\mathrm{ab}}$ & $2,84^{\mathrm{a}}$ \\
F2 & $3,44^{\mathrm{a}}$ & $3,60^{\mathrm{a}}$ & $3,60^{\mathrm{a}}$ & $3,12^{\mathrm{a}}$ & $3,64^{\mathrm{ab}}$ & $3,72^{\mathrm{bc}}$ \\
F3 & $3,80^{\mathrm{ab}}$ & $3,60^{\mathrm{a}}$ & $3,68^{\mathrm{a}}$ & $3,28^{\mathrm{a}}$ & $3,60^{\mathrm{a}}$ & $3,64^{\mathrm{bc}}$ \\
F4 & $4,24^{\mathrm{b}}$ & $4,20^{\mathrm{b}}$ & $3,84^{\mathrm{a}}$ & $3,32^{\mathrm{a}}$ & $3,96^{\mathrm{ab}}$ & $4,04^{\mathrm{c}}$ \\
F5 & $4,20^{\mathrm{b}}$ & $4,12^{\mathrm{b}}$ & $3,60^{\mathrm{a}}$ & $3,20^{\mathrm{a}}$ & $4,16^{\mathrm{b}}$ & $3,56^{\mathrm{b}}$ \\
\hline
\end{tabular}

*notasi huruf yang berbeda menunjukkan beda nyata antar baris pada taraf signifikasi $(\alpha) 5 \%$.

Keterangan : F1 : Laktosa 100\%, F2 : Laktosa 80\%: Manitol 20\%, F3 : Laktosa 50\% : Manitol 50\%, F4 : Laktosa 20\% : Manitol 80\%, F5 : Manitol 100\% 


\section{Aroma}

Aroma berhubungan dengan sensori penciuman panelis terhadap produk. aroma produk pangan dipengaruhi oleh bahan pangan, proses pengolahan, maupun penyimpanan (Saragih, 2014). Dari parameter aroma, berdasarkan Tabel 5 penggunaan pengisi laktosa-manitol tidak berpengaruh secara signifikan terhadap tingkat penerimaan panelis pada aroma minuman effervescent. Nilai rata-rata tingkat kesukaan panelis terhadap kenampakan minuman effervescent labu siam dan ekstrak secang berkisar 3,12-3,32 dengan nilai netral. Dari parameter aroma minuman, yang paling disukai yaitu tablet dengan pengisi laktosa $20 \%$ : manitol $80 \%$.

\section{Rasa}

Dari parameter rasa, effervescent yang menggunakan pengisi manitol $100 \%$ berbeda nyata dengan effervescent yang menggunakan pengisi laktosa 50\% : manitol
$50 \%$. Nilai rata-rata tingkat kesukaan panelis terhadap rasa minuman effervescent labu siam dan ekstrak secang 3,60-4,16 dengan kisaran nilai netral hingga suka. Effervescent yang menggunakan pengisi manitol merupakan minuman yang paling disukai panelis, hal ini diduga karena manitol selain manis juga mempunyai sensasi dingin di mulut (Rowe et al., 2006).

\section{Overall}

Parameter overall digunakan untuk mengukur tingkat kesukaan panelis terhadap warna dan kenampakan tablet, serta kenampakan, aroma dan rasa minuman effervescent labu siam dan ekstrak secang. Nilai rata-rata tingkat kesukaan panelis terhadap rasa minuman effervescent labu siam dan ekstrak secang 2,84-4,04 dengan kisaran nilai tidak suka hingga suka. Dari segi overall, penggunaan pengisi laktosamanitol berpengaruh terhadap tingkat kesukaan panelis.

Tabel 6 Uji Pembobotan

\begin{tabular}{|c|c|c|c|c|c|c|c|}
\hline \multirow{2}{*}{ Karakteristik } & \multirow{2}{*}{ BV } & \multirow{2}{*}{$\mathrm{BN}$} & $\mathrm{F} 1$ & $\mathrm{~F} 2$ & F3 & F4 & F5 \\
\hline & & & $\mathrm{NH}$ & $\mathrm{NH}$ & $\mathrm{NH}$ & $\mathrm{NH}$ & $\mathrm{NH}$ \\
\hline \multicolumn{8}{|l|}{ Kimia } \\
\hline Kadar air & 2 & 0,091 & 0,000 & 0,003 & 0,031 & 0,072 & 0,091 \\
\hline $\mathrm{pH}$ & 1 & 0,045 & 0,044 & 0,045 & 0,000 & 0,027 & 0,021 \\
\hline Antioksidan & 2 & 0,091 & 0,054 & 0,000 & 0,072 & 0,072 & 0,091 \\
\hline \multicolumn{8}{|l|}{ Fisik granul } \\
\hline Porositas & 1 & 0,045 & 0,045 & 0,020 & 0,010 & 0,008 & 0,000 \\
\hline Kompresibilitas & 1 & 0,045 & 0,000 & 0,008 & 0,032 & 0,034 & 0,045 \\
\hline Kecepatan alir & 1 & 0,045 & 0,039 & 0,045 & 0,019 & 0,009 & 0,000 \\
\hline Sudut diam & 1 & 0,045 & 0,000 & 0,005 & 0,013 & 0,036 & 0,045 \\
\hline \multicolumn{8}{|l|}{ Fisik tablet } \\
\hline Kekerasan & 1 & 0,045 & 0,030 & 0,045 & 0,019 & 0,011 & 0,000 \\
\hline Kerapuhan & 1 & 0,045 & 0,035 & 0,045 & 0,032 & 0,018 & 0,000 \\
\hline Waktu larut & 2 & 0,091 & 0,040 & 0,000 & 0,035 & 0,068 & 0,091 \\
\hline $\mathrm{CV}$ & 1 & 0,045 & 0,022 & 0,004 & 0,014 & 0,045 & 0,000 \\
\hline Ketebalan & 1 & 0,045 & 0,000 & 0,016 & 0,023 & 0,038 & 0,045 \\
\hline Diameter & 1 & 0,045 & 0,000 & 0,013 & 0,029 & 0,045 & 0,039 \\
\hline \multicolumn{8}{|l|}{ Sensoris } \\
\hline Warna tablet & 1 & 0,045 & 0,032 & 0,000 & 0,020 & 0,045 & 0,043 \\
\hline Kenampakan tablet & 1 & 0,045 & 0,000 & 0,011 & 0,011 & 0,045 & 0,041 \\
\hline \multicolumn{8}{|l|}{ Kenampakan } \\
\hline minuman & 1 & 0,045 & 0,023 & 0,000 & 0,015 & 0,045 & 0,000 \\
\hline Aroma & 1 & 0,045 & 0,018 & 0,000 & 0,036 & 0,045 & 0,018 \\
\hline Rasa & 1 & 0,045 & 0,026 & 0,003 & 0,000 & 0,029 & 0,045 \\
\hline \multirow[t]{2}{*}{ Overall } & 1 & 0,045 & 0,000 & 0,033 & 0,030 & 0,045 & 0,027 \\
\hline & 22 & & 0,410 & 0,298 & 0,444 & 0,742 & 0,644 \\
\hline
\end{tabular}

Keterangan : BV = Bobot Variabel, BN= Bobot Normal, $\mathrm{NH}=$ Nilai Hasil 


\section{Uji Pembobotan}

Uji Pembobotan dilakukan untuk mengetahui formulasi terbaik. Penentuan formulasi terbaik effervescent labu siam dan ekstrak secang dilakukan berdasarkan hasil analisis sifat kimia, fisik granul, fisik tablet maupun hasil uji sensoris. Uji ini mengacu Sullivan et al. (2015), tentang penentuan formulasi terbaik bakso ikan dengan metode compensatory. Prinsip pengujian metode compensatory adalah memberikan bobot (score) sesuai dengan kontribusi suatu karakterisitik terhadap formula yang dihasilkan. Berdasarkan Tabel 6 didapatkan $\mathrm{NH}$ (Nilai hasil) tertinggi yaitu pada formulasi F4 sehingga formulasi terbaik yaitu effervescent yang menggunakan pengisi laktosa 20 : manitol $80 \%$.

\section{KESIMPULAN}

Penggunaan laktosa, manitol, dan kombinasi keduanya sebagai bahan pengisi berpengaruh terhadap porositas, kompresibilitas, kecepatan alir, sudut diam granul, kekerasan, kerapuhan, waktu larut tablet, warna dan kenampakan tablet serta rasa dan overall minuman effervescent, namun tidak berpengaruh secara signifikan terhadap kadar air, $\mathrm{pH}$, aktivitas antioksidan, kenampakan dan aroma minuman effervescent. Berdasarkan hasil uji pembobotan didapatkan formula tablet terpilih yaitu effervescent yang menggunakan pengisi laktosa $20 \%$ : manitol $80 \%$.

\section{DAFTAR PUSTAKA}

Abdillah, Alvin. 2012. Pengaruh Jenis dan Konsentrasi Bahan pengikat terhadap Karakteristik Fisik Serta Analisa Aktivitas Antioksidan Tablet Effervescent dari Ekstrak Buah Beet (Beta vulgaris). Skripsi. Fakultas Pertanian Universitas Sebelas Maret.

Allen, Loyd V., Nicholas G. Popovich, Howard C. Ansel, 2009. Pharmaceutical Dosage Forms and Drug Delivery System Ninth Edition. Lippincott Williams \& Wilkins. Philadelpia.
Ansar., Budi Rahardjo, Zuheid Noor, dan Rochmadi. 2010. Analisis Dimensi Proses Pelarutan Tablet Effervescent Sari Buah Markisa. Agritech, Vol. 30, No. 1.

Ansar., Rahardjo B, Noor Z, Suyitno. 2006. Optimasi Formula dan Gaya Tekan Terhadap Sifat Tablet Effervescent dari Buah Markisa. Jurnal Teknologi dan Industri Pangan, 17(1): 23-27.

Ansel. H,C., 1989, Pengantar Bentuk Sediaan Farmasi, (Terjemahan). Universitas Indonesia Press. Jakarta.

Anwar, Khoerul. 2010. Formulasi Sediaan Tablet Effervescent dari Eksrak Kunyit (Curcuma domestica Val.) dengan Variasi Jumlah Asam Sitrat-Asam Tartat. Jurnal Sains dan Terapan Kimia Vol.4(2): 168-178

AOAC (Official Methods of Analysis). 1999. Association of Official Analytical Chemists. Washington

Aslani, Abolfazl., and Hajar Jahangiri. 2013. Formulation, Characterization and Physicochemical Evaluation of Ranitidine Effervescent Tablets. Advanced Pharmaceutical Bulletin.

Badan Pengawas Obat dan Makanan RI. 2014. Persyaratan Mutu Obat Tradisional.

Bhise S R., Kaur A. and Manikantan M.R. 2014. Moisture Dependent Physical Properties of Wheat Grain (PBW 621). International Journal of Engineering Practical Research Vol.3(2):40-45.

Dewi, Rosmala., Iskandarsyah, dan Devi Octarina. 2014. Tablet Effervescent Ekstrak Belimbing Wuluh (Averrhoa bilimbi L.) dengan variasi Kadar Pemanis Aspartam. Pharmaceutical Science Research, Vol 1 (2): 116-133.

Direktorat Jenderal Hortikultura. 2015. Statistika Produksi Holtikultura Tahun 2014. Kementrian Pertanian

Eichie, F. E. and Kudehinbu, A. O. 2009. Effect of particle size of granules on some mechanical properties of 
paracetamol tablets. African Journal of Biotechnology Vol. 8 (21).

Estiasih, Teti dan Ahmadi. 2009. Teknologi Pengolahan Pangan. Bumi Aksara : Malang.

Faradiba, Nursiah Hasyim, dan Zahriati. 2013. Formulasi Granul Effervescent Ekstrak Etanol Daun Jambu Biji (Psidium guajava LINN). Majalah Farmasi dan Farmakologi, Vol. 17, No.2

Hartono, Henry Purnawidya. 2008. Karakteristik Fisik Dan Organoleptik Tablet Effervescent Putih Telur Bercitarasa Lemon Dengan Konsentrasi Effervescent Mix Yang Berbeda. Skripsi. Institut Pertanian Bogor

Ismaiel, Mostafa Mahmoud Sami., Yassin Mahmoud El-Ayouty, Michele PierceyNormore. 2016. Role of $\mathrm{pH}$ on antioxidants production by Spirulina (Arthrospira) platensis. Brazilian Journal of Microbiology.

Juliyanto, Fitra. 2010. Pembinaan Kelompok Tani Melalui Pengolahan Labu Siam (Sechium edule Sw.) Di Kecamatan Caringin Kabupaten Sukabumi Provinsi Jawa Barat. Jurnal Penyuluhan Pertanian, Vol. 5 No. 1.

Kailaku, Sari Intan., Jayeng Sumangat dan Hernani. 2012. Formulasi Granul Efervesent Kaya Antioksidan dari Ekstrak Daun Gambir. J. Pascapanen 9(1).

Kholidah, Sitti., Yuliet, dan Akhmad Khumaidi. 2014. Formulasi Tablet Effervescent Jahe ( $Z$ Officinale Roscoe) dengan Variasi Konsentrasi Sumber Asam dan Basa. Online Jurnal of Natural Science, Vol.3(3): 216-229.

Koswara, Sutrisno. 2009. Pewarna Alami : Produksi dan Penggunaannya. eBookPangan.com

Lachman, Leon., Herbert A. Lieberman, Joseph L. Kanig. 1989. Teori dan Praktek Farmasi Industri. UI Press : Jakarta.
Lieberman, Herbert A., Leon Lachman, joseph B. Schwartz. 1989. Pharmaceutical Dosage Forms Tablets Volume 1. Marcel Dekker, INC.

Lumay, G., F. Boschini, K. Traina, S. Bontepi, J.C Remy, R. Cloots, N. Vandewalle. 2012. Measuring the Flowing Properties of Powders and Grains. Journal of Powder Technology Vol. 224:19-27.

Miksusanti, Elfita, dan Hotdelina S. 2012. Aktivitas Antioksidan dan Sifat Kestabilan Warna Campuran Ekstrak Etil Asetat Kulit Buah Manggis (Garcinia mangostana L.) dan Kayu Secang (Caesalpinia sappan L.). Jurnal Penelitian Sains, Volume 15 Nomor 2.

Pratiwi, Galih., Triana Hertiani dan Mufrod. 2011. Optimasi Komposisi Sukrosa dan Aspartam Sebagai Bahan Pemanis Pada Formula Tablet-Effervescent Ekstrak Etanolik Buah Mengkudu. Majalah Obat Tradisional, 16(2), 43-50.

Pribadi, Yoga Sindi, Sukatiningsih, Puspita Sari. 2014.Formulasi Tablet Effervescent Berbahan Baku Kulit Buah Naga Merah (Hylocereus polyrhizus) dan Buah Salam (Syzygium polyanthum [Wight.] Walp). Berkala Ilmiah Pertanian Volume 1, Nomor 4.

Pudiastuti, RSP., Ilham Kuncahyo, dan Soebiyanto. 2009. Pengaruh Jenis Pengikat Terhadap Mutu Fisik Tablet Effervescent Ekstrak Pegagan (Centella Asiatica Urb.). Jurnal Kimia dan Teknologi: (49-52).

Rowe, Raymond C., Paul J Sheskey, Sian C Owen. 2006. Handbook of Pharmaceutical Excipients fift Edition. Pharmaceutical Press

Rusdi, Udju D., W. Widowati dan E.T. Marlina. 2005. Efek Ekstrak Kayu Secang, Vitamin E dan dan vitamin C terhadap Status Antioksidan Total (SAT) Pada Mencit yang terpapar Aflatoksin. Media Kedokteran Hewan, Vol 21 No 2.

Saifullah, M., Y.A. Yusof, N.L Chin, M.G Aziz. 2016. Physicochemical and Flow Properties of Fruit Powder and Their 
Effect on the Dissolution of Fast Dissolving Fruit Powder Tablets. Journal Powder Technology Vol. 30(1):394-404.

Saptono, Haryadi., Aulanni'am, Herawati. 2013. Terapi Perasan Buah Labu Siam (Sechium edule) terhadap Aktivitas Protease dan Gambaran Histopatologi Kolon Tikus (Rattus norvegicus) IBD (Inflammatory bowel disease) Hasil Induksi Indometasin. Program Studi Pendidikan Dokter Hewan, Program Kedokteran Hewan, Universitas Brawijaya

Saragih, Raskita. 2014. Uji Kesukaan Panelis Pada Teh Daun Torbangun (Coleus amboinicus). E-Journal Widya Kesehatan dan Lingkungan Volume 1 Nomor 1.

Septian, Markus. 2010. Pengaruh Pemberian Ekstrak Labu Siam (Sechium edule (Jacq.) Sw.) Terhadap Kadar Trigliserida Darah Tikus Putih (Rattus norvegicus) yang Diinduksi dengan Pemberian Pakan Hiperkolesterolemik. Skripsi. Fakultas Kedokteran Universitas Sebelas Maret Surakarta.

Setiawan, Rizki Dwi. 2012. Kajian Karakteristik Fisik dan Sensoris Serta Aktivitas Antioksidan dari Granul Effervescent Buah Beet (Beta vulgaris) dengan Perbedaan Metode Granulasi dan Kombinasi Sumber Asam. Skripsi. Fakultas Pertanian Universitas Sebelas Maret.

Sullivan, William G., Elin M.Wicks, C. Patrick Koelling 2015. Engineering Economy Sixteenth Edition. Pearson Higher Education. United States of America.

Tomar, Neha., Mohit Tomar, Neha Gulati and Upendra Nagaich. 2012. Formulation and Evaluation of Fast Disintegrating Tablets of Caffeine by Using Effervescent Formulation Approach. Der Pharmacia Lettre, 4 (5)

Violalita, Fidela., dan Rini B. 2015. The Effect Acid Addition on Characteristic Effervescent Tablet of Tamarillo.
International Journal on Advanced Science Engineering Information Technology Vol.5 (3).

Wijayati, Muthmaina., Nyi M. Saptarini, Irma E. Herawatil, Shelvy E. Suherman. 2014. Formulasi Granul Effervescent Sari Kering Lidah Buaya Sebagai Makanan Tambahan. IJPST, Volume 1, Nomor 1. 